\title{
Academic Career Prestige Viewed by Russian University Students ${ }^{1}$
}

\section{Franz Edmundovich Sheregi ${ }^{1}$}

\section{Volodimir Vasil'evich Hoblik²}

\author{
${ }^{1}$ National Research Nuclear University (MEPhl), Moscow, Russian Federation \\ Email: f-sheregi@inbox-ru \\ ${ }^{2}$ Mukachevo State University, Mukachevo, Ukraina
}

\section{Doi:10.5901/mjss.2015.v6n4s4p352}

\begin{abstract}
The Russian Science and Humanities today are not just going through a difficult period of renovation but continuing crisis. There are several reasons to this situation: lack of demand for researchers in industry, relatively low wages of academics, migration of academics into commerce, emigration abroad, a low iprestige of Science and Humanities in views of young people and, caused by the abovementioned, a steady aging of academia. Based on the data of all-Russia studies, the article reveals the structural dysfunctionality of academia personnel including the residual presence of a large non-productive personnel, the reasons of academia aging and the reluctance of University graduates to choose an academic career, graduates decrease as a result of the negative impact of the "demographic" pit and, therefore, a lack of graduate students.
\end{abstract}

Keywords: academic personnel, career guidance, university students, occupational prestige, academic career

\section{Introduction}

Personnel shortage in the economies of all developed countries, and especially in the sphere of intellectual activity, is aggravated by unfavorable demographic situation, the cause of which is not only a natural decline in birthrate, but also the continuing negative impact of the "demographic hole" as " an echo" of the World war of the twentieth century. For example, from the late 1990s on, the population of the Russian Federation has been annually reducing by an average of 0.5 million of people, resulting in the situation that by 2014 the number of graduates from Russian universities decreased by $35 \%$.

The increased role of science in the defense and civil commodity production, the origins of which can be attributed to the middle of the XIX century, led to the necessity to permanently update the socio-professional structure of the society, which does not only imply an increased professional mobility, but life-long learning of personnel in many industries and services .

Integration into the world economy based on the principles of market economy resulted in the situation when the Russian economy experienced a considerable shortage of professionals able to perform their occupational functions in a dynamic, innovative production. In Russian, innovative production representatives tend to aim at accelerating the process of the staff replacement, which, in its turn, leads to an accelerated generations rotation: employers determining the employees' age brackets trigger personnel shortages as the innovative character of modern production demands a high proportion of employees with analytical skills and practical experience. The resulting situation is as follows: Russia experiences an acute shortage of professionals able of analytical thinking and implementing research outcomes into production, thus increasing its competitiveness in domestic and international markets of goods and services.

Research institutions in all spheres of the Russian economy also experience a lack of academics and thus are unable to fulfill their main task which is to provide for innovative production. In 1990-2000, Russian research institutions deprived of major commercial orders for research and development managed to stay afloat thanks to state financing only. Researchers salaries in those times plummeted dramatically.

Analytically thinking professionals able to transform research outcomes in innovative mass production were to have been educated and trained in higher educational institutions. But in the 1990s, having received a considerable

\footnotetext{
1 The research presented in the article is based on the data received as a result of the analysis performed by the Agreement with the Ministry of Education and Science of the Russian Federation № 03.573.21.0004 on Subsidy Provision, Issued on September 22, 2014 (Code "2014-03-573-0029-002").
} 
amount of autonomy, universities committed themselves to making money, establishing numerous departments which typically provided some kind of humanitarian courses on a paying basis. Much less effort was invested into educating modern engineers, analysts and managers of science, which implies selection of students with analytical thinking.

As a result, since early 1990s, graduates of higher educational institutions, able to pursue research and implement innovations into manufacturing, were no longer in demand. The Russian academia's crisis of that period was caused by two main problems: adverse demand for research and academic staff shortages. The social prestige of science dropped and researchers themselves began discussing a deep crisis in intellectual spheres. Even in 2005, when the socioeconomic situation in Russia was relatively stable, the share of researchers negatively characterizing Russian academia (from stagnation to decline) was $94 \%$, in 2011 the share decreased to $86.5 \%$ and only by May 2015 this figure fell to $62.3 \%$. All the above mentioned testifies to the tendencies, but not a favorable situation².

Under the circumstances, educating analytically minded professionals for innovative production and researchers for academic organizations became challenging. The interest in such intellectual professions is still demonstrated by an average of $6 \%$ of university students, and after the graduation, no more than $0.5 \%$ are attracted by research organizations or development laboratories of manufacturing companies.

The authors of the article search for the causes of permanent and extremely long lasting low prestige of a researcher shared by university students and possible ways to improve the situation enhancing Russian academia prestige.

The problem has recently attracted a number of researchers whose publications provide views on the situation in Russian academia and its causes. Among the most distinguished works we find articles, books and monographs of Members of the Russian Academy M.K. Gorshkov (Gorshkov and Klyucharev, 2011), G.V. Osipov (Osipov, 2014), professors D.L. Konstantinovsky (Konstantinovsky et al, 2011), G.A. Klyucharev (Klyucharev, 2011).

The research presented in the article is based on the survey conducted by the Center for Social Forecasting and Marketing in May 2015. The Survey was pursued in 200 Russian universities, 2.200 students of Years $1-5$ were interviewed (Head of the Project, professor F.E. Sheregi).

\section{Analysis: Changes in Academia}

\subsection{Social Changes in Academia}

Comparative statistical analysis shows that as early as in the "Russian period" (from 1997 to 2005.) the national system went through a significant reduction in the number of design and survey providers, research institutions, pilot plants (Indicators of Science, 2014, p. 26; see Fig. 1). This decline is not the result of these organizations' optimization but absence of demand for their services and products. During the period of structural reforms of the 1990s universities also lost many of their design and project organizations as well as pilot plants, it happened primarily due to the sharp reduction in the number of commercial contracts signed.

Before the above mentioned reforms of 1990 -s, commercial contracts made up to at least $80 \%$ of the budget of research departments of Universities.

Between 1995 and 2012 the total number of employees in research institutions of the Russian Federation decreased by 1.5 times, and number of researchers dropped by 1.4 times (Indicators of Science, 2014, p. 37; see Fig. 2).

\footnotetext{
${ }_{2}^{2}$ The data used are from The Nationwide Surveys 2005, 2011 and 2015 conducted by the Center for Social Forecasting and Marketing
} in 2005, 2011 and 2015 respectively. 


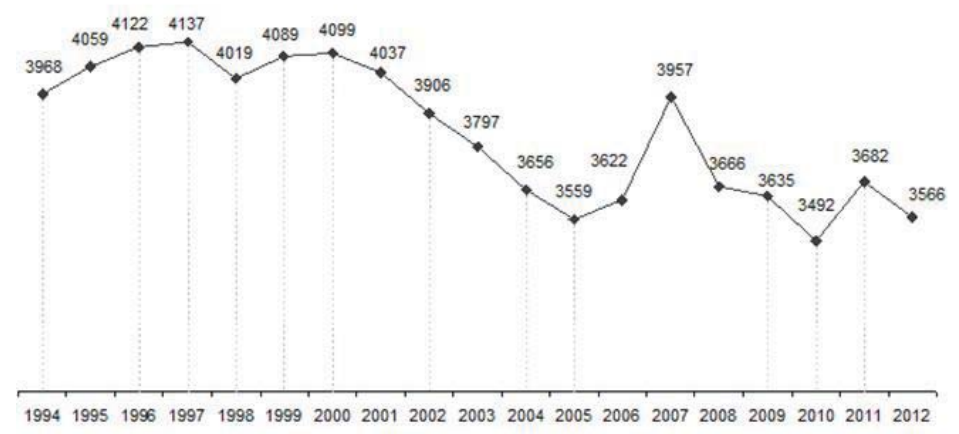

Figure 1. The Number of Organizations Engaged in Research and Development (years 1994-2012)

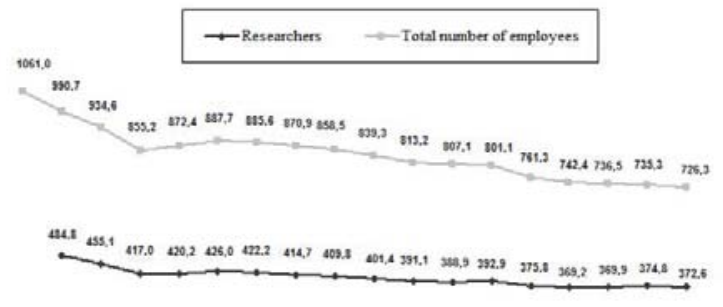

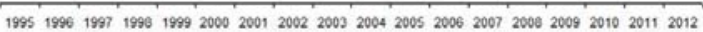

Figure 2. The number of employees engaged in research and development in the years 1995-2012 (part-time employees and civil contract employees)

The low inflow of young professionals in academic institutions led to academia aging: in 1994 an average researcher was 58 years old, in 2012 - 63, the average age of candidiates of science raised from 45 to 48 years, doctors - from 49 to 52 years (Indicator of Science, 2014, p. 49). As a result, the share of researchers under the age of 40 was reduced to less than 33\% in all types of research institutions: academic and industry research institutions as well as in university research organizations (See Table 1) ${ }^{3}$.

Table 1. The Age Structure of Researchers in Various Research Institutions with Different Forms of Ownership, \%

\begin{tabular}{|l|c|c|c|}
\hline \multirow{2}{*}{ Age } & \multicolumn{3}{|c|}{ Supreme Institutions } \\
\cline { 2 - 4 } & $\begin{array}{c}\text { Russian Academy of } \\
\text { Sciences }\end{array}$ & $\begin{array}{c}\text { Industry Institutions and } \\
\text { Organizations }\end{array}$ & $\begin{array}{c}\text { Higher Educational } \\
\text { Institutions }\end{array}$ \\
\hline Under 30 years including & 17,2 & 13,8 & 16,9 \\
\hline $31-35$ years & 10,0 & 6,1 & 8,8 \\
\hline $36-40$ years & 7,1 & 6,7 & 5,1 \\
\hline $41-50$ years & 22,5 & 20,1 & 19,1 \\
\hline $51-60$ years & 26,7 & 27,9 & 31,6 \\
\hline Over 60 years & 16,5 & 25,4 & 18,5 \\
\hline Total & 100 & 100 & 100 \\
\hline Average age & 47,1 & 50,5 & 48,4 \\
\hline Share of researchers under 40 years old & 27,9 & 26,6 & 30,8 \\
\hline
\end{tabular}

3 The results of all-Russia survey conducted by the Center for Social Forecasting and Marketing in 2012, the representative sample includes the results of the survey of 2200 academia personnel employed in academic and industrial research organizations. 
The causes of unpopularity of an academic career become clear and obvious if we trace a typical "route" of a Russian academician. There is typically a 3.6.year gap between graduation from the university and enrollment for a post-graduate course, and there is usually 14.8 year gap between the Candidate and Doctorate dissertations. That means that it takes a University graduate a period of $21-23$ years to write and present a Doctorate dissertation. By this time, the researcher with the intention to "prove his/her academic validity" and following the inherited from the Soviet times system is to celebrate at least his/her $40^{\text {th }}$ birthday. Residing either in Moscow or St. Petersburg (two Russian cities where the majority of Russian researchers live and where the cost of living is the highest in the country) with the average monthly salary of 32.5 thousand rubles (Indicator of Science, 2014, p. 151), a researchers has next to no chances to provide for the family and buy a flat. The salary also keeps losing its purchasing value due to the ongoing ruble devaluation. Thus, from 1995 to 2012 the average salary of the personnel engaged in research and development increased 107 times, but if the calculation is conducted in US dollars it increased only 16.5 times (Indicators of Science, 2014, pp. 5, 110; See Bar Chart 1). Due to the changes in ruble value in November 2014, the purchasing power of salaries dropped, compared to year 2012 , by at least $50 \%$.

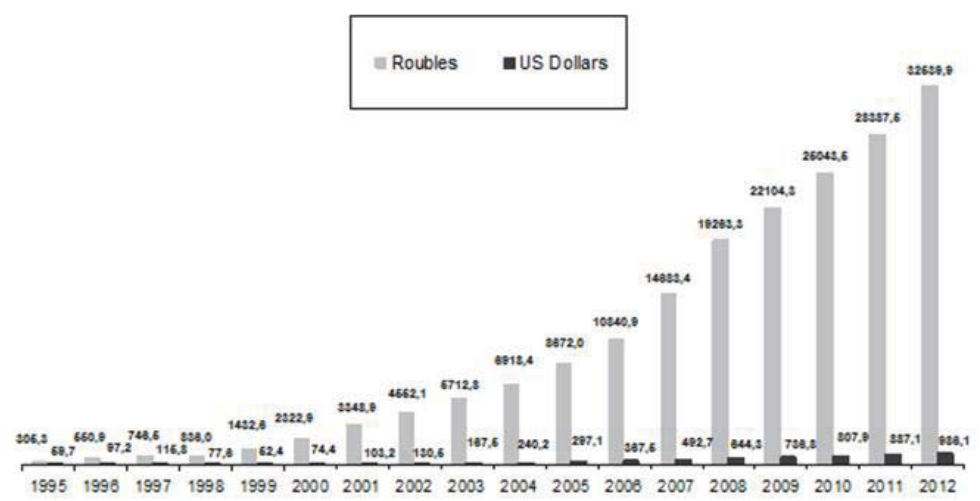

Bar Chart 1. The Average Monthly Salary of the Personnel Engaged in Research and Development

Dissatisfied with the salary the most active researchers change their academic careers for something more profitable, those who remain in research institutions are often the so-called " dead wood". The all-Russia survey conducted by the Center for Social Forecasting and Marketing demonstrated that only $68.2 \%$ of academicians consider science and research as their primary professional vocation, while $31.8 \%$ of employees of research institutions "found themselves in their offices irrespective of their wish due to some kind of circumstances". It is quite possible that among that third of the researchers "trapped" in academic communities there are few of those whose career as a researcher is rather fruitful. However, the statistics shows that the majority of researchers working in academia due to "life circumstances" prove to have very low research results. The science is not done by those who were forced to do it, with probably one exception and that is for some kind of auxiliary work. Frustrations and dissatisfaction with the work done, aggravated if some practical outcomes are required, stimulate such like employees to seek for other forms of their "scientificity" acknowledgment and results in nothing but a dissertation defense, usually when the researcher is quite advanced in years.

\subsection{Negative Factors in Academia}

The research demonstrated the three integral factors in today's Russia hampering the development of research, they are financial causes, personnel reasons and administrative interference. These claims of researchers translated into the vernacular sound simple: academics have no money, they are aging, they leave research institutions as they can not work " in chancery" of the existing bureaucratic system. These factors strongly promote the migration of scholars out of academic and resrach institutions.. In all cases, the main reason of the migration of scientists is underpayment.

The most variable is the motivation of researchers leaving for Russian commerce and emigrating into economically developed countries. In the first case, the predominant motives are as follows: low wages $\Rightarrow$ low prestige of an academic 
career in society $\Rightarrow$ ambiguity of life perspectives $\Rightarrow$ no evidence of personal professional growth $\Rightarrow$ worsening working conditions in fundamental science. In the second case the motives are: low wages $\Rightarrow$ worsening working conditions in fundamental science $\Rightarrow$ concerns for the fate of children $\Rightarrow$ low prestige of an academic career in society $\Rightarrow$ ambiguity life perspectives $\Rightarrow$ instability of the political situation in Russia.

Since 1990s the migration or "outflow" of academic personnel from research institutions was also aggravated by weak "inflow" of young professionals into academic institutions though Universities increased admission quotas for postgraduate courses. The process reached its peak in years 1990-2005 when the average "inflow" of young professionals into academic institutions was 40\% less than that in 1960-1989. Due to the sharp reduction of the number of researchers and the reluctance of young people to fill the resulting personnel "gap" in 1990-2005, supreme bodies had to resort to staff reduction: as a result in the period from 1995 to 2005 the total number of research institutions decreased by 500 units (Science in the Russian Federation, 2005, p. 24; Gudkova, Mindeli, 2005, p. 5; Key Performance Indicators of Research Organizations, 2005, p. 5), and the total number of researchers in academic institutions - by 124,600 people (Science in Russia in Figures, 2005, p. 46; Science in Russia, 2001, p. 20; 2005 Year Data: Main Indicators of Organizations Engaged in Research and Development, 2006, p. 5).

In late 2000s, Russian authorities realized the relevance of innovative development of the country's economy and the need to replenish the staff losses in research organizations with young professionals. However, the results of the study indicate that modern university graduates do not consider academic careers as prestigious. Professional plans of graduates are not predetermined by the social significance of a particular profession, but by its prestige and profitability. Based on the last two criteria academic careers of a researcher or a University lecturer are considered by University students much less attractive than those of an economist, lawyer, designer and a manager Professional plans of students are not predetermined by the social significance of a particular profession and its prestige and profitability (See Fig. 3).

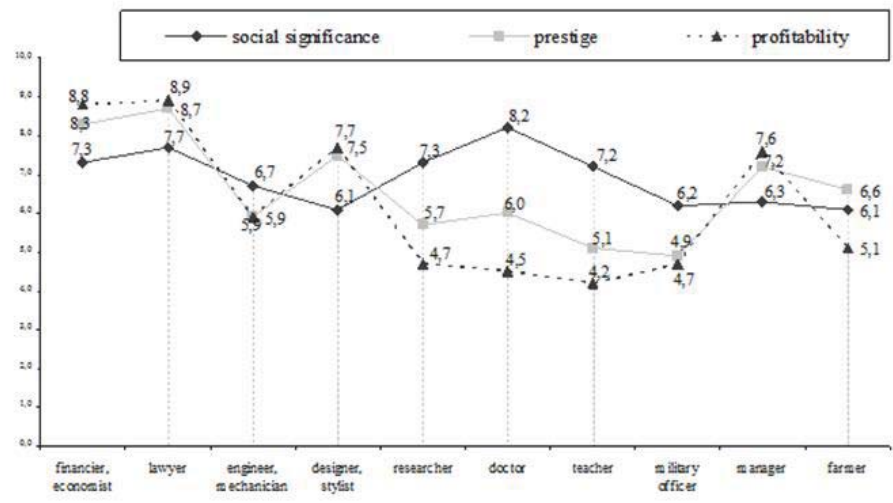

Figure 3. Russian Universities Students' Evaluation of the Social Significance, Prestige and Profitability of Major Professions (on a ten-point scale)

\subsection{Changes in the Structure of Russian University Graduates}

In 1990-2000-ies there were dramatic changes in University education and curricula. The most notable innovation of those times was appearance of private universities: in 2014 there were 391 non-government Universities, which mainly trained students in Humanities: Social Sciences, Economics and Management. In year 1994, private universities issued degrees to only 1\% (3.400 people) of all Russian universities graduates, but in 2012 the number increased to 17.9\% (231,000 people)(Education in the Russian Federation, 2014, p. 355). State universities also experienced an increase in the number of graduates majoring Humanities and Social sciences. The number of graduates with degrees in science plummeted dramatically though the demand for the latter was still high (Education in the Russian Federation, 2014, p. 384; see Table. 2). 
Table 2. The Structure of Public Higher Education Institutions Graduates, in thous. of people

\begin{tabular}{|l|c|c|c|c|}
\hline & 1990 & 2004 & 2013. & $\begin{array}{c}\text { Increase ratio / } \\
\text { reduction range in years } \\
1990-2013\end{array}$ \\
\hline The Total Number of Graduates & 401,1 & 1076,6 & 1291,0 & 3,2 \\
\hline INCLUDING: & 393,1 & 989,0 & 1114,3 & 2,8 \\
\hline Science, Physics and Maths & 35,9 & 32,6 & 18,6 & 0,5 \\
\hline Humanities and Social Studies & 48,9 & 205,4 & 227,3 & 4,6 \\
\hline Education and Pedagogy & 41,3 & 130,8 & 89,8 & 2,2 \\
\hline Health & 24,6 & 27,1 & 36,5 & 1,5 \\
\hline Cultural Studies and Arts & 12,8 & 15,9 & 20,3 & 1,6 \\
\hline Economics and Management & 55,5 & 337,0 & 449,1 & 8,1 \\
\hline Geology, Exploration and Development of Mineral Resources, Geodesy and Land-Utilization & 7,0 & 12,9 & 21,8 & 3,1 \\
\hline Power Economy, Power Engineering and Electronics & 8,8 & 20,0 & 23,1 & 2,6 \\
\hline Metallurgy, Machine Building and Metal Processing & 27,9 & 24,0 & 18,7 & 0,7 \\
\hline Aviation, Rocket and Space Technology & 4,4 & 4,7 & 4,3 & 1,0 \\
\hline Transport & 11,9 & 29,5 & 36,6 & 3,1 \\
\hline Instrumentation and Optical Engineering & 3,9 & 26,2 & 33,2 & \\
\hline Electronic Engineering, Radio Engineering and Telecommunications & 17,0 & 14,6 & 11,3 & \\
\hline Automation and Control & 10,8 & 10,6 & 12,6 & 0,7 \\
\hline Computer Science and Engineering, Information Security & 7,1 & 11,5 & 16,2 & 1,2 \\
\hline Chemistry and Biotechnology & 7,2 & 9,8 & 8,1 & 2,3 \\
\hline Technology of Food Products and Consumer Goods & 17,4 & 15,8 & 15,3 & 1,1 \\
\hline Architecture and Construction & 22,6 & 26,7 & 39,4 & 0,9 \\
\hline Agriculture and Fishing Industry, Processing and Reproduction of Forest Resources & 29,7 & 38,5 & 36,8 & 1,7 \\
\hline Other Disciplines & 6,5 & 7,7 & 13,3 & 1,2 \\
\hline
\end{tabular}

The overall trend summarized from the data in Table 2 demonstrates that over the period from 1990 to 2013 the number of graduates from Departments of Economics and Management increased 8.1 times, from the Departments of Humanities, Social Sciences and Education - 3.3 times. Universities trained 1.7 times more students for Technical degrees, Architecture and Construction - 1.7 times, Health - 1. 5 times. The growth of graduates for Agriculture, Forestry and Fishing Industry was quite moderate - 1.2 times. There was very little increase in the number of graduates from Chemistry and Biotechnology Departments: the increase ratio was 1.1. In Departments of Science, Physics and Mathematics the number of graduates fell twice: the reduction range was 0.5 .

\subsection{Quality of Training and Problems of Private Universities}

There are problems related to the quality of graduates, it is especially true about private Universities, the majority of which (74\%) appeared in the last five year period - from 1991 to 1995. It is a very short period of time even for state universities as their establishment, organization and development require large investments. The majority of new Universities lacked the capital needed, thus they faced a number of problems, sometimes quite acute. Functioning of Universities was hampered by:

- Lack of facilities;

- Meager budgets;

- Lack of the required amount of permanently employed academics ;

- Lack of the required number and profiles of laboratories;

- Lack of an established technology of training;

- Lack or inadequate supply of literature in research libraries;

- Absence or lack of piloted and approved textbooks and teaching materials;

- Instability of private universities status in the overall system of higher education in Russia.

\subsection{Students' Professional Choices Analysis}

\subsubsection{Informativeness}

The presented description of a students' environment in Russian Universities makes the foundation of a graduate's 
professional choice analysis.

Students' primary familiarizing with the profession of a researcher starts when they are involved in the studies conducted by Universities faculties. But the data on the number of students' being motivated and ready to participate in the research can be considered reliable only in case all students are informed about the range of studies held by University academia. All-Russia survey conducted by the Center for Social Forecasting and Marketing, shows that only $42.7 \%$ of students today receive complete information about their Universities research activities.

It must be emphasized that in universities where students' research work is well organized, at least a third of students learn about it in the first and second years at the University. The share of final year students learning about the research is only $6 \%$. The rule of thumb here is simple: if 3rd year students are ignorant of the research work, the faculty do not pursue any studies.

Students' participation in the University research work is aimed at identification of students' creative abilities. As they are still going through their initial stage of professional development, many of them are not aware of their talents and gifts. Therefore, whether students participate in research or not to a greater degree depends on how the research and its dissemination are being organized by the faculty. The survey held in 2013 proved $31 \%$ of the students were able to evaluate the organization of research work at the Department (i.e. had enough information). And only $17 \%$ assessed organization of the research work at the Department as "good".

\subsubsection{Voluntary Participation}

Research is a creative activity, and creativeness implies free choices: one can not be made to create. This principle is always taken into account in organizing all types of research work, therefore, as a rule, students participation in it is voluntary. Today, $61 \%$ of students in Russian universities demonstrate no interest in research, and only $8 \%$ of students enjoy doing the research. It is probably the real amount of Russian students who are capable of research and independent studies.

In fact, it is a potential indicator of Russian scientific personnel and Universities academia. The estimation of the Center for Social Forecasting and Marketing published in December 2014 proves that due to the so called "demographic pit" the faculty research personnel "replenishment" in absolute figures is not going to be complete until 2019 and the number of post graduates is to decrease up to year 2021 (see Bar charts. 2 - 3).

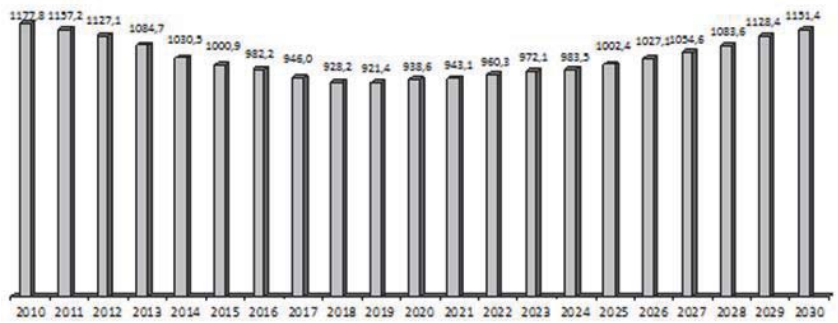

Bar Chart 2. The Number of Higher Educational Institutions Graduates

The Russian Federation and Forecast to 2030, in thousands.

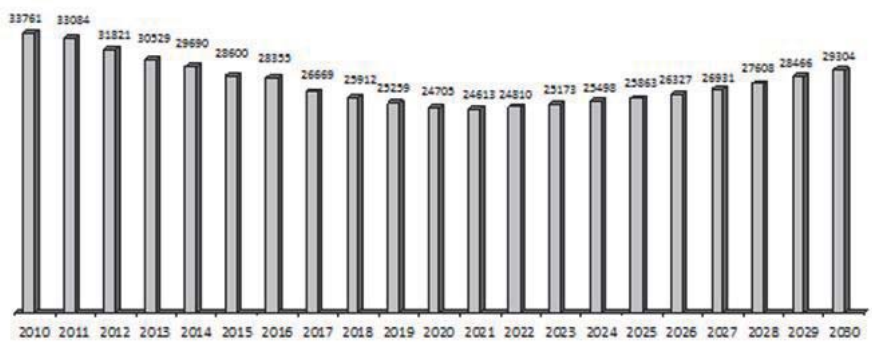

Bar Chart 3. The Number of Post-graduate of the Russian Federation and the Forecast until 2030, capita 
In most cases, students participate in the four forms of research work: data collection and its processing, laboratory (field) research, empirical data analysis, research technical maintenance. Only 2 - 3\% of students are paid for the research conducted, typically these are students of Engineering and Technical departments. All the rest are rewarded with extra points for the courses they take and are free to use the data in their course papers, thesis and dissertations.

\subsubsection{Students' Views on Research}

Only $29 \%$ of students are confident that participation in the research work may be beneficial for their individual development, $71 \%$ of the rest interviewees were not able to make any comments on the matter. Students' self-motivation for research work participation is as follows: research helps to expand occupational knowledge, develops study skills, assists occupational internship which is beneficial in adapting to the future job duties. It also helps to verify creative abilities and to understand whether it is worth pursuing studies in the future. The other two arguments for the research are as follows, it helps to assimilate in the professional community and, in rare cases, gives a chance to make money. As we see the arguments enumerated are not completely opportunistic, which indicates that students' views are well-judged and elaborated. They realize that a research is first of all a process of intellectual production, and a poundage point of view is not going to guarantee good results.

While making the choice for the research, the majority of students are attracted by possible discoveries, independent creative work, and social prestige of an academic career. However, in many cases criticism of the present situation is aimed at inefficient management of students' research. About $10 \%$ of students find causes of their frustration in research in the following: negligence, unfair practices, lack of novelty, lack of enjoyment, commercialism, bad facilities.

Remunerative incentive is not what motivatesUniversity students to participate in research. The two main arguments for the research are cognition interest and professional development. They both may be considered sincere and natural as at University students do not consider research as a career or a family income resource (see. Bar Chart 4).

\subsubsection{Post Graduate Schools Vacancies}

At the moment the ratio of students ready to take a postgraduate course is rather high, it is on average $27 \%$. After a postgraduate course, $22 \%$, i.e. $6 \%$ of the total number of students, are planning to pursue a career of a researcher, and only $14 \%$, i.e. $4 \%$ of the total number of students, are preparing themselves for a teaching career at the University .

Thus, the present situation is far from being simple: at the moment post graduate schools accept only Master courses graduates. In year 2013, 49.6 thousand people (Education in the Russian Federation, 2014, p. 361) received Master courses diplomas, $27 \%$ of whom make 13.400 - that is the number of those who were applying for a postgraduate course. In year 2012, Russian postgraduate schools admission capacity was as high as 45600 . These figures forecast that this and in the future only $29.4 \%$ of postgraduate schools admission capacities are to be filled. The probability of such like development is quite high if postgraduate courses in the Russian Federation are recognized as the third level of higher education and only Mater courses graduates are legitimate for admission. Under the circumstances, there are three ways to solve the problem of completing the lacking two thirds of admission quotas: firstly, to invite and admit less talented and motivated Master courses graduates (but academia is unlikely to benefit from this choice); secondly, to admit previous years graduates; thirdly (which is the most probable development), 2-fold reduction of graduate schools admission quotas. 


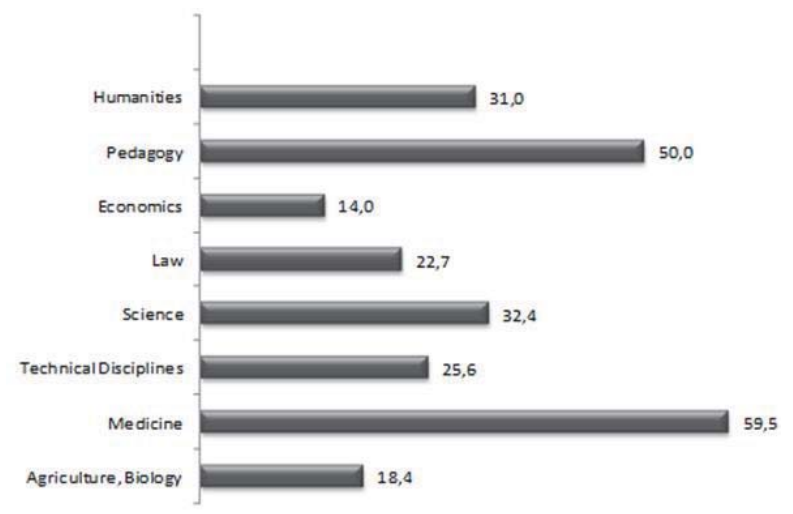

Bar Chart 4. The Ratio of Students Majoring Different Subjects Confident in Research Activities Being Beneficial for their Development, \%

\section{Conclusions and Discussion}

The empirical data collected by the Center for Social Forecasting and Marketing suggest the following general conclusions.

The situation in Russian academia differs greatly from the situation in the industrialized countries of the West, Where Biotechnology, Biochemistry, Medicine, Human Sciences, Ecology, Engineering are among the most popular disciplines. Not by chance, 1990-s Russian emigrants to the West were predominantly professionals from those areas; some biological laboratories were closed as all the personnel emigrated from the country. At the moment, the situation is about the same: developed countries continue to import most talented and promising scientists from Russia. At the same time, Russian economists, political scientists, lawyers and representatives of other mass ( in terms of number of researchers) social studies and humanities are in the least prone to migration (emigration) and almost entirely continue their careers in Russia, mainly in the University sector. Social and Humanitarian spheres employ only $5 \%$ of the total number of Russian researchers, while the ratio of "humanitarians" in the structure of Russian graduates is $50 \%$.

Thus, the recruitment problem in Russian academia is far from being solved and there are several reasons to this:

- $\quad$ Reduction of college graduates and post-graduate due to the existing "demographic pit";

- Low attractiveness for young people due to low material incentives of academic careers;

- Ineffective academia career guidance in universities, poor facilities, a wide gap between teaching and research;

- Pragmatically oriented education as a result of curriculum reduction: the removal of philosophical disciplines from the curriculum resulted in students' developing formal logic, not analytic thinking.

The latter is probably the main cause hampering the students' grasping the research algorithm which moves to the truth not only "through hardships", but also through paradoxes. These problems of University training, guidance and research turn into problems of Russian economy which being oriented at innovations requires analytically thing innovative engineers and research managers.

\section{References}

Education in the Russian Federation (2014). Moscow: National Research University - Higher School of Economics. Moscow. (In Russian).

Gorshkov, M.K., Klutcharev G.A. (2011) Continuous education is in the context of modernization. Moscow: IS RAS (In Russian).

Gurvich, V. (2002) The Poverty Caused by Being Clever. There are Staff Shortages in the Global High-Tech Market. Independent Review. August 2. (In Russian).

Gudkov, A.A., Mindeli L.E. (2005). Status, Trends and Prospects of Development of the Organizational Structure of Russian Science: the Institution al Aspect. Newsletter. CSRS, 2005, 4. (In Russian).

Indicators of Science (2014). Statistical Yearbook. Moscow: National Research University - Higher School of Economics.(in Russian).

Key Performance Indicators of Research Organizations (2005). Moscow: Federal State Statistics Service, vol. 1. 
Kljutscarov, G. Didenko D. (2014) On the Resources of Russian Modernization: the Role of the Continuous Education in the Process of Capital Accumulation. Russian Education and Society. Vol.56, 2014, 2, 3-29.

Klutcharev, G.A. (2014) The index of "professional ballast" among graduates of vocational education institutions). Measurement of University Rankings: International And Russian Experience. Ed.by G.V. Osipov and A.L. Arefiev. Moscow: Center for Sociological Research, 453-469. (In Russian).

Kobzeva, N.I. (2012). Teaching University Students the Scientific Image of the World as a Subject of Research. Siberian Pedagogical Journal, 5, 179-182. (In Russian).

Kobzeva, N.I. (2012). Special Aspects of Teaching University Students the Scientific Image of the World as a Subject of Research. Bulletin of the Orenburg State University, 7, 100-104. (In Russian).

Konstattinovskiy, D.L., Voznesenskaya E.D., Cherednichenko G.A., Hohlushikina F.A. (2011). Education and Life Trajectories of Youth: 1998-2008 Years. Moscow: IS RAS, 2011.(in Russian).

Main Indicators of Organizations Performing Research (2006). January-December 2005. Moscow: Federal State Statistics Service. Vol. I. (In Russian).

Measurement of University Rankings: International and Russian Experience (2014). Ed.by G.V. Osipov and A.L. Arefiev. Moscow: Center for Sociological Research, 453-469. (In Russian).

Mironov, V.A., Maikova, E.Y. (2004). The Social Aspects of University Students Research Activities. Tver: TSTU. (In Russian).

Most Prestigious and Lucrative Profession (2013). Far East Information and Advertising Portal. [Online] Available:http://www.dvreclama.ru/Russia/analytics/259+1/samye_vostrebovannye_professii_vs_sammye_prestizhnye__dokhodnye_ professii_opros_ vtsiom/ December 10. (In Russian).

Nekipelova, E.D. (1998). Emigration and Professional Activities of Russian Academics Abroad. Moscow: CSRS. (In Russian).

Onopriyenko, V.I. (2007). Generations in Science: a sociologist view. Sociological Research. 2007, 4, 75-85. (In Russian).

Osipov, G.V, Strikhanov M.N., Sheregi F.E. (2014). The relationship of Science And Industry. Sociological Analysis. Moscow: Center for Social Forecasting and Marketing, in 2 parts. (In Russian).

Russian Science in Figures (2005). Statistical Yearbook. Moscow: CSRS, 2005 (In Russian).

Savelieva, O.O. (1999). Russian science through the eyes of students. Herald of the Russian Academy of Sciences, 3, $203-207$ (In Russian).

Science in Russia (2001). Statistical Yearbook. Moscow: State Committee on Statistics. Centre for Science Research and Statistics (In Russian).

Science in the Russian Federation (2005). Moscow: The State University - Higher School of Economics. (In Russian).

Sheregi, F.E, Arefiev A.L., Rybakovsky L.L., Savinkov V.I. (2013). The Number of Students And Staff of Educational Institutions of the Russian Federation: Forecast to Year 2020 and Trends Assessment up to Year 2030). Moscow: Center for Social Forecasting and Marketing. (In Russian).

Zubova, L.G.(2008). Orientating graduates to academic careers. Sociological research, 11, 119-123. (In Russian). 